\title{
ADDITION OF SUPERIOR HETEROTROF BACTERIA MIXED IN FEED TO IMPROVE HEALTH OF SALINE TILAPIA Oreochromis niloticus
}

\author{
Lewi Maraditha Simanjuntak $^{1^{*}}$, Iesje Lukistyowati ${ }^{2}$, F. Feliatra ${ }^{2}$ \\ ${ }^{1}$ Student of The Faculty of Fisheries and Marine Science University of Riau, Pekanbaru \\ ${ }^{2}$ Lecturer at The Faculty of Fisheries and Marine Science University of Riau, Pekanbaru \\ *Lewi.maradithasimanjuntak@student.unri.ac.id
}

\begin{abstract}
This research was conducted in May 2019 until July 2019 which took place at the Laboratory of Marine Microbiology and the Laboratory of Fish Parasites and Diseases at the Faculty of Fisheries and Maritime Affairs, Riau University. The purpose of this study was to determine the effect of the addition of superior heterotrophic bacterial isolates that were sprayed on feed could affect the health of saline tilapia (Oreochromis niloticus) through erythrocyte and leukocyte blood images. The treatments are $\mathrm{Kn}, \mathrm{Kp}$, feed sprayed with B.cereus heterotrophic bacterial isolate solution $(0.15 \%$ dose $)$, feed sprayed with heterotrophic $V$. fluvialis bacterial isolate solution ( $0.15 \%$ dose), feed sprayed with combined Isolate solution. The results of the study of the addition of superior heterotrophic bacterial isolates sprayed on feed can improve the health of saline tilapia (Oreochromis niloticus) after 30 days of maintenance and post-infection of Aeromonas hydrophila bacteria showed that the treatment of P3 (combined isolates) which is the best treatment with a total leukocyte value of 89.67 x 103 cells / mm3, lymphocytes $80.33 \%$, neutrophils $10.67 \%$, monocytes $9.66 \%$, total erythrocytes $235.00 \times 104$ cells / mm3, hematocrit $32.00 \%$ and hemoglobin $7.33 \mathrm{~g} / \mathrm{dL}$ and weight growth absolute $7.05 \mathrm{~g}$, a survival rate of $83.33 \%$.
\end{abstract}

Keywords: Aeromonas hydrophila, Erythrocytes, Hematocrit, Hemoglobin, Heterotrophic bacteria, Leukocytes, Oreochromis niloticus

\section{PENDAHULUAN}

Ikan nila (Oreochromis niloticus) merupakan satu jenis ikan air tawar yang populer di kalangan masyarakat. Ikan nila sangat potensial dan produktif apabila dibudidaya di berbagai lahan, bukan hanya di kolam tetapi juga dipelihara di tambaktambak air payau, serta di lahan sawah baik sebagai penyelang, palawija maupun minapadi. Hal ini karena ikan nila memiliki batasan toleransi yang cukup tinggi terhadap berbagai kondisi lingkungan perairan (Aliyas et al., 2016).

Penyakit yang timbul dalam proses budidaya tambak disebabkan karena interaksi antara ikan, lingkungan dan patogen yang tidak berada dalam keseimbangan. Meningkatnya intensifikasi budidaya juga memiliki dampak terhadap serangan penyakit pada ikan nila khususnya Aeromonas hydrophila. Penanggulangan penyakit ikan pada akuakultur telah sering dilakukan dengan menggunakan berbagai antibiotik, tindakan ini sangat merugikan. Penggunaan antibiotik secara terus menerus dan bila penggunaannya tidak tepat dapat menyebabkan bakteri patogen menjadi resisten, terjadi penimbunan residu obat-obatan di dalam tubuh ikan dan lingkungan perairan yang akhirnya 
berbahaya bagi konsumen yang mengkonsumsinya (Lukistyowati dan Syawal, 2013).

Menurut Feliatra et al. (2019), isolat bakteri heterotrof mampu menghambat pertumbuhan bakteri Vibrio sp, Aeromonas sp dan Pseudomonas sp dikarenakan oleh beberapa faktor seperti: produksi antibiotik, bakteriosin, siderphores, lisosom, protease dan hidrogen peroksida atau mempengaruhi $\mathrm{pH}$ media dengan menghasilkan asam organik tertentu.

Berdasarkan uraian di atas penulis tertarik untuk melakukan penelitian pengaplikasian bakteri heterotrofik dicampur ke dalam pakan untuk meningkatkan kesehatan ikan nila salin (O. niloticus).

Tujuan penelitian ini adalah untuk mengetahui penambahan isolat bakteri heterotrof yang disemprotkan pada pakan dapat meningkatkan kesehatan ikan nila salin melalui gambaran darah sehingga tahan terhadap penyakit dan nilai produksi dapat meningkat.

\section{METODE PENELITIAN}

Penelitian ini telah dilaksanakan pada bulan Mei sampai Agustus 2019 bertempat di Laboratorium Parasit dan Penyakit Ikan Jurusan Budidaya Perairan dan Laboratorium Mikrobiologi Laut Jurusan Ilmu Kelautan, Fakultas Perikanan dan Kelautan Universitas Riau.

Metode penelitian yang digunakan adalah metode eksperimen menggunakan rancangan acak lengkap (RAL), lima taraf perlakuan dengan tiga kali ulangan yaitu : Kn (pemberian pakan tanpa penambahan bakteri heterotrof dan tanpa diujitantang), $\mathrm{Kp}$ (pemberian pakan tanpa penambahan bakteri heterotrof dan diujitantang), P1 (Pakan yang disemprot larutan Isolat bakteri heterotrof $B$. cereus dosis $0,15 \%$ ), P2 (Pakan yang disemprot larutan Isolat bakteri heterotrof $V$. fluvalis dosis 0,15\%), dan P3 (Pakan yang disemprot larutan Isolat gabungan $V$. fluvalis dan $B$. cereus dosis $0,15 \%$ ).

\section{Alat dan Bahan}

Alat yang digunakan yaitu autoclave, Timbangan analitik, erlenmayer, hot plate, laminar flow, mikropipet, lampu bunsen, gelas ukur, vortex, wadah ember $16 \mathrm{~L}$, magnetik stirrer, cawan petri, tabung reaksi, inkubator, alumunium foil, jarum ose, $\mathrm{pH}$ meter, haemositometer, mikroskop binokuler, hand counter, centrifuse, thermometer, refractometer, penggaris, aerator, selang, camera, syringe, objek dan cover glass

Bahan yang digunakan yaitu akuades, ikan nila salin, alkohol $70 \%$, minyak cengkeh, larutan $\mathrm{NaCl}$, Larutan Turk, larutan hayem, $\mathrm{HCl} 0,1 \mathrm{~N}, \mathrm{Na}$ Sitrat 3,8\%, giemsa dan metanol, Minyak Emersi, GSP (Glutamact Starch Penile), NA (Natrium Agar), NB (Natrium Broth), Tryptone Soya Agar (TSA), Tryptone Soya Broth (TSB), A. hydrophila, pelet komersil, dan bakteri heterotrof isolat $V$. fluvialis dan B. cereus

\section{Persiapan Wadah}

Wadah pemeliharaan yang digunakan adalah ember yang berukuran $16 \mathrm{~L}$ sebanyak 15 buah. Sebelum wadah digunakan terlebih dahulu dibersihkan dan direndam menggunakan methylene blue dengan dosis 1-2 mL untuk $10 \mathrm{~L}$ air.

\section{Persiapan Bakteri Heterotrof}

Media NA digunakan untuk peremajaan isolat bakteri heterotrof. Larutan media disterilisasi menggunakan autoclave pada suhu $121^{0} \mathrm{C}$ selama 15 menit, kemudian isolat diinkubasi pada suhu $28^{\circ} \mathrm{C} 24$ jam. Setelah itu, dilakukan produksi kembali ke dalam media $\mathrm{NB}$ dan diencerkan dengan kepadatan $10^{5} \mathrm{CFU} / \mathrm{mL}$ yang diukur menggunakan spektofotometer (Nainggolan, 2018).

\section{Persiapan Pakan}

Pakan ikan yang digunakan adalah pelet komersial kandungan protein hingga $39-41 \%$ dan kadar lemak 5\% yang disemprot dengan bakteri heterotrof. 
Bakteri heterotrof sebanyak $15 \mathrm{~mL}$ dimasukkan ke dalam $250 \mathrm{~mL}$ akuades + $2,25 \mathrm{~mL} \mathrm{NaCl}$ pada gelas ukur (Setiawati et al., 2013), sehingga didapatkan volume larutan masing-masing perlakuan sebanyak $267.25 \mathrm{~mL} / \mathrm{kg}$ pakan.

\section{Pemeliharaan Ikan Uji}

Ikan uji yang digunakan benih ikan nila salin (O. niloticus) berukuran $4-6 \mathrm{~cm}$ dengan kepadatan 1 ekor/L dengan jumlah ikan 10 ekor setiap wadah. Pemeliharaan dilakukan selama 30 hari dan selama pemeliharaan ikan diberi pakan komersial secara ad satiations. Setiap 10 hari dilakukan sampling sebanyak 50\% dan dilakukan penimbangan bobot ikan. Pada hari ke 30 dilakukan pengambilan darah. Pada hari ke 34 dilakukan uji tantang dengan menggunakan bakteri $A$. hydrophila dan pada hari ke 48 dilakukan kembali pengambilan darah untuk hasil akhir (Alfian et al., 2017).

\section{Penyediaan Bakteri A.hydrophila}

Biakan A. hydrophila merupakan koleksi Laboratorium Parasit dan Penyakit Ikan diganaskan terlebih dahulu dengan cara direinfeksi kembali pada ikan kemudian ditumbuhkan pada media GSP (Glutamate Starch Phenol). Koloni yang tumbuh berwarna kuning diambil 1 koloni kemudian diisolasi ke media TSA hingga didapatkan koloni yang seragam dan murni (Lukistyowati dan Kurniasih, 2011).

\section{Uji Tantang}

Setelah pemeliharaan selama 30 hari dengan perlakuan, ikan diujitantang menggunakan bakteri A. hydrophila disuntikkan secara intramuscular dengan dosis 0,1 mL/ekor dan kepadatan $10^{5}$ $\mathrm{CFU} / \mathrm{mL}$.

\section{Pengamatan Gejala Klinis}

Pengamatan gejala klinis dilakukan untuk mengetahui tingkah laku ikan selama pemberian pakan mengandung bakteri heterotrof dan juga setelah ikan diinfeksi
A.hydrophila meliputi perubahan morfologi dan tingkah laku.

\section{Total Leukosit}

Menurut Blaxhall dan Daisley dalam Dosin et al. (2013), metode pengukuran total leukosit yaitu sampel darah dihisap dengan pipet skala 0,5 dilanjutkan dengan menghisap larutan turk's sampai skala 11, kemudian dihomogenkan dengan cara mengoyanggoyangkan membentuk angka delapan. diteteskan ke dalam haemositometer dan ditutup dengan cover glass. Penghitungan dilakukan pada 4 kotak besar haemositometer dan jumlahnya dihitung:

\section{Jumlah Leukosit $=$ Jumlah sel leukosit terhitung x $50 \mathrm{sel} / \mathrm{mm}^{3}$}

\section{Diferensiasi Leukosit}

Preparat ulas darah pada kaca objek lalu dikeringanginkan, selanjutnya difiksasi dengan larutan methanol $95 \%$ selama 5 menit, setelah itu dibilas dengan akuades, dilanjutkan dengan pewarnaan giemsa, setelah itu dicuci dengan air mengalir, dan diamati di bawah mikroskop dengan pembesaran 400x. Jenis leukosit yang diamati adalah limfosit, monosit dan neutrofil.

\section{Total Eritrosit}

Menurut Blaxhall dan Diesley dalam Dosin et al. (2013), metode pengukuran total eritrosit, yaitu sampel darah dihisap dengan pipet skala 0,5 dilanjutkan dengan menghisap larutan hayem sampai skala 101, kemudian dihomogenkan dengan cara digoyanggoyangkan membentuk angka delapan dan diteteskan ke dalam haemositometer dan ditutup dengan cover glass. Penghitungan dilakukan pada 5 kotak kecil haemositometer dan jumlahnya dihitung dengan rumus :

$$
\begin{aligned}
& \text { Jumlah Eritrosit }=\mathbf{J u m l a h} \text { sel eritrosit } \mathbf{x} \\
& 10^{4} \mathrm{sel} / \mathrm{mm}^{3}
\end{aligned}
$$




\section{Kadar Hematokrit}

Sampel darah dimasukkan kedalam tabung mikro hematokrit sampai kira kira 4/5 bagian tabung, sumbat ujungnya (bertanda merah) dengan kretoseal kemudian disentrifuse (Anderson dan Siwicki dalam Dosin et al., 2013).

\section{Kadar Hemoglobin}

Kadar hemoglobin diukur dengan mengacu Wedemayer dan Yasutake dalam Dosin et al. (2013) dengan cara: tabung sahlinometer diisi dengan larutan HCL 0,1 $\mathrm{N}$ sampai angka 10 lalu darah ikan diambil dari tabung mikrotube dengan pipet sahli sebanyak 0,02 mL dan didiamkan 3 menit. Kemudian ditambahkan akuades dengan pipet tetes sedikit demi sedikit sambil diaduk dengan gelas pengaduk sampai warnanya tepat sama dengan warna standar.

\section{Tingkat Kelulusan Hidup}

Untuk mengukur kelangsungan hidup ikan uji digunakan rumus dari Zonneveld $e t$ al. (1991) sebagai berikut :

$$
S R=\frac{\mathrm{Nt}}{N 0} \times 100 \%
$$

Dimana :

$$
\begin{aligned}
\mathrm{SR} & =\text { Tingkat kelulushidupan }(\%) \\
\mathrm{Nt} & =\text { Populasi ikan pada masa akhir } \\
& \text { pemeliharaan } \\
\mathrm{N} & =\begin{array}{l}
\text { Populasi ikan pada masa awal } \\
\text { pemeliharaan }
\end{array}
\end{aligned}
$$
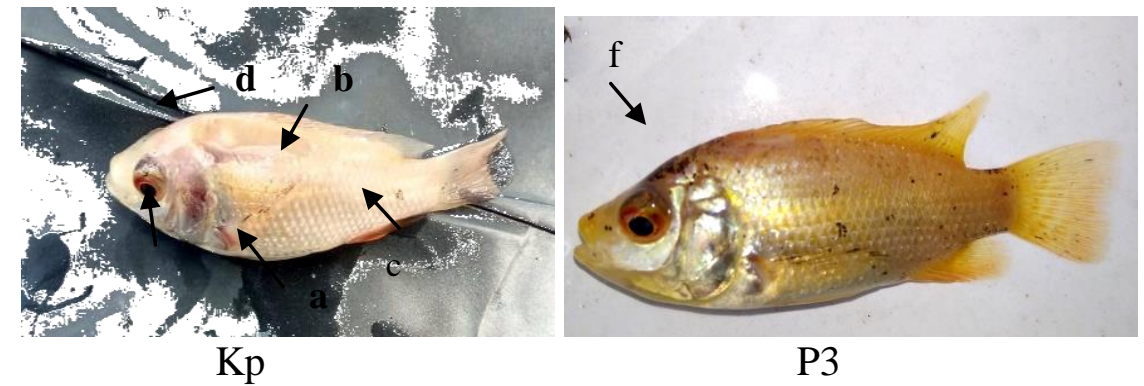

Gambar 1. Gejala Klinis Ikan Nila Salin (Oreochromis niloticus) yang diberi Pakan Mengandung Bakteri Heterotrof Unggul Pascaujitantang Bakteri A. hydrophila

Keterangan: a). Sisik lepas b). Warna tubuh pucat c). Sirip rusak, d). Luka melebar(daging rusak), e). Mata keruh, f). luka pada bekas suntikan mulai menutup 
Ikan perlakuan menunjukkan fase penyembuhan dengan luka yang mulai menutup. Hal ini sesuai dengan pendapat Frandson dalam Lukistyowati dan Kurniasih (2012) yang menyatakan bahwa fibrinogen keluar dari pembuluh darah dan menyebabkan timbulnya koagulasi pada jaringan yang membantu dalam membuat barier terhadap menyebarnya unsur-unsur infeksi sehingga membangun dinding untuk wilayah yang sedang mengalami kerusakan.

\section{Total Leukosit}

Hasil pengamatan terhadap total leukosit ikan nila salin setelah pemeliharaan selama 30 hari berkisar antara $42,00-83,33 \times 10^{3} \mathrm{sel} / \mathrm{mm}^{3}$. Dapat dilihat pada Tabel 1.

Tabel 1.Total Leukosit pada Ikan Nila Salin (O. niloticus) dengan Pemberian Pakan Mengandung Bakteri Heterotrof

\begin{tabular}{|c|c|c|}
\hline \multirow[b]{2}{*}{ Perlakuan } & \multicolumn{2}{|c|}{ Total Leukosit x $10^{3} \mathrm{sel} / \mathrm{mm}^{3}$} \\
\hline & Hari ke- 30 Pemeliharaan & Hari ke-14 Pascaujitantang \\
\hline $\mathrm{Kn}$ & $43,67 \pm 1,53^{\mathrm{a}}$ & $49,00 \pm 1,00^{\mathrm{a}}$ \\
\hline $\mathrm{Kp}$ & $42,00 \pm 2,00^{\mathrm{a}}$ & $60,67 \pm 1,15^{b}$ \\
\hline $\mathrm{P} 1$ & $61,67 \pm 1,52^{b}$ & $71,00 \pm 1,73^{\mathrm{c}}$ \\
\hline $\mathrm{P} 2$ & $72,33 \pm 2,51^{\mathrm{c}}$ & $77,33 \pm 1,52^{\mathrm{d}}$ \\
\hline P3 & $83,33 \pm 4,93^{\mathrm{d}}$ & $89,67 \pm 1,52^{\mathrm{e}}$ \\
\hline
\end{tabular}

Nilai total leukosit tertinggi ikan nila salin yang diberi pakan mengandung bakteri heterotrof terdapat pada perlakuan $\mathrm{P}_{3}$ (Isolat gabungan) sebesar 83,33 $\times 10^{3}$ $\mathrm{sel} / \mathrm{mm}^{3}$ (Gambar 2) hal ini terjadi karena pemberian bakteri heterotrof gabungan semakin efektif dalam meningkatkan kecernaan pakan dengan enzim pencernaan yang dihasilkan B.cereus seperti amilase, protease, lipase dan selulosa memudahkan penyerapan nutrien oleh tubuh ikan sehingga pertumbuhan baik dan meningkatkan sistem imun yang memproduksi antibodi pada tubuh ikan.

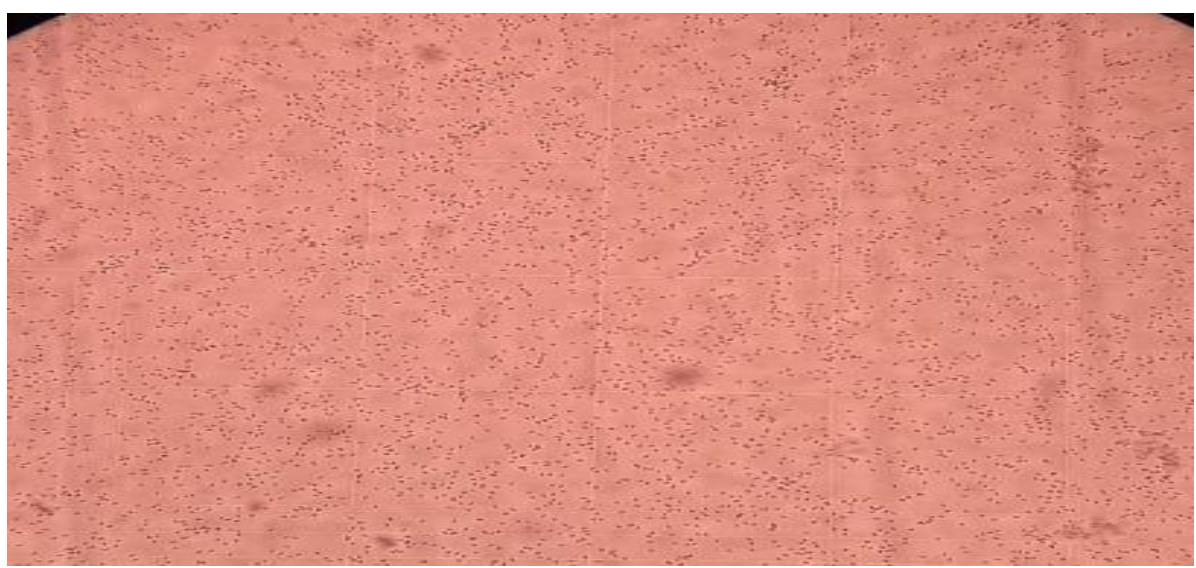

Gambar 2. Total leukosit Ikan Nila Salin Perlakuan P3

Total leukosit tertinggi pascaujitantang terdapat pada perlakuan $\mathrm{P}_{3}$ dengan nilai $89,67 \times 10^{3} \mathrm{sel} / \mathrm{mm}^{3}$ berbeda nyata dengan perlakuan Kp sebesar 60,67 x
$10^{3} \mathrm{sel} / \mathrm{mm}^{3}$. Naiknya nilai leukosit dalam darah disebabkan oleh ikan stres akibat serangan patogen, dan fagositosis terhadap patogen sehingga limfosit terus mem- 
produksi zat kebalnya dan monosit berdiferensiasi menjadi makrofag.

Perlakuan Kontrol positif tanpa pemberian bakteri heterotrof yang diujitantang juga mengalami peningkatan total leukosit sangat tinggi dikarenakan ikan mengalami stres dan terus memproduksi zat kebal dalam melawan patogen.

Berdasarkan hasil uji statistik (ANOVA) menunjukkan bahwa nilai total leukosit ikan nila salin yang diberi pakan mengandung bakteri heterotrof berpengaruh nyata terhadap total leukosit ikan nila salin pascaujitantang dengan $A$. hydrophila $(\mathrm{P}<0,05)$. Sehingga diduga perpaduan dua jenis bakteri heterotrof Vagococcus sp dan Bacillus sp ini semakin unggul dalam meningkatkan kesehatan ikan nila salin, senyawa-senyawa yang dihasilkan seperti antibiotik, bakteriosin, siderphores, lisosom dan protease.

\section{Diferensiasi Leukosit}

Pengamatan diferensiasi leukosit bertujuan untuk mengetahui perbedaan persentase komponen sel leukosit. Nilai diferensiasi leukosit yang diambil merupakan rata-rata persentase tiga jenis sel leukosit yaitu, limfosit, neutrofil dan monosit (Gambar 2).

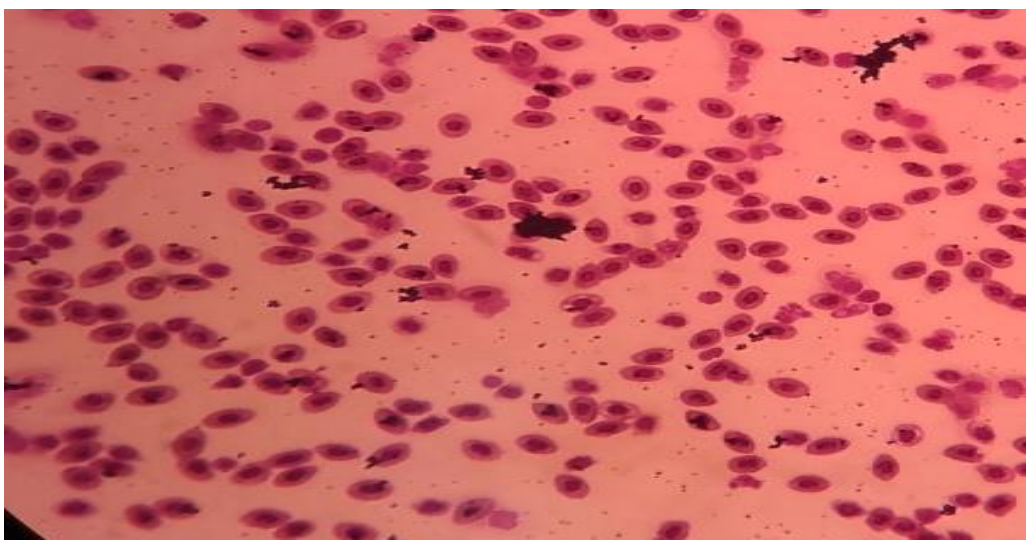

Gambar 3. Diferensiasi Leukosit 30 Hari pemeliharaan dengan Perlakuan P3

Jumlah sel limfosit ikan nila salin setelah pemeliharaan selama 30 hari dengan pemberian perlakuan berkisar antara 85,33-88,33\%. Nilai limfosit tertinggi diperoleh pada perlakuan $\mathrm{P}_{3}$ sebesar $88,33 \%$ hal ini dikarenakan $B$. cereus dan $V$. fluvialis meningkatkan kecernaan dan penyerapan nutrien seperti protein yang berguna untuk imunostimulan.

Pakan mengandung bakteri heterotrof memiliki pengaruh terhadap nilai limfosit, hal ini diduga karena limfosit digunakan untuk menghasilkan antibodi dalam menyerang sel-sel asing yang masuk ke dalam tubuh. Mundriyanto et al. (2002), menyatakan bahwa mekanisme kerja sel limfosit dalam peranannya sebagai sistem kekebalan tubuh berfungsi menyediakan zat kebal untuk pertahanan tubuh dengan cara mengenali antigen melalui reseptor spesifik pada membran sel.

Jumlah sel neutrofil ikan nila salin setelah pemeliharaan selama 30 hari dengan pemberian perlakuan berkisar antara 6,00-8,33\%. Namun, setelah dilakukan penginfeksian terhadap ikan uji dengan A. hydrophila didapatkan peningkatan jumlah proporsi neutrofil yang menunjukkan bahwa ikan uji terserang $A$. hydrophila. Persentase neutrofil berkisar antara $7,67 \%-13,33 \% . \mathrm{P}_{3} 10,67 \%$, nilai ini mengalami peningkatan jika dibandingkan Kn sebesar 7,67\%.

Jumlah sel monosit ikan nila salin setelah pemeliharaan selama 30 hari dengan pemberian perlakuan berkisar antara 5,00-6,33\%. Persentase monosit pasca ujitantang perlakuan P3 mengalami 
kenaikan monosit paling rendah hal tersebut dikarenakan P3 memiliki sistem imun yang tinggi dari bakteri heterotrof sehingga kenaikan monosit tidak drastis.

\section{Total Eritrosit}

Total eritrosit selama pemeliharaan 30 hari dengan pemberian perlakuan berkisar antara 220,00-278,33 x $10^{4}$ $\mathrm{sel} / \mathrm{mm}^{3}$. Hasil ini masih berada dalam kisaran normal sesuai pernyataan Irianto
(2005), jumlah eriitrosit ikan teleostei berkisar antara $105-300 \times 10^{4} \mathrm{sel} / \mathrm{mm}^{3}$.

Peningkatan jumlah eritrosit disebabkan karena penambahan bakteri heterotrof yang mampu meningkatkan kerja organ pencernaan sehingga nafsu makan ikan meningkat, asupan nutrien cukup baik dan sistem imun terbentuk baik pula. Putra (2010), menambahkan bahwa probiotik menghasilkan beberapa enzim untuk pencernaan pakan seperti amilase, protease, lipase dan selulose.

Tabel 2. Total Eritrosit pada Ikan Nila Salin (Oreochromis niloticus) dengan Pemberian Pakan mengandung Bakteri Heterotrof

\begin{tabular}{lcc}
\hline \multirow{2}{*}{ Perlakuan } & \multicolumn{2}{c}{ Total Eritrosit $\mathbf{~} \mathbf{1 0}^{\mathbf{4}} \mathbf{~ s e l} / \mathbf{m m}^{\mathbf{3}}$} \\
\cline { 2 - 3 } & Hari ke-30 pemeliharaan sebelum uji & Hari ke 14 Pasca Uji Tantang \\
tantang & $239,33 \pm 2,64^{\mathrm{a}}$ \\
Kn & $220,00 \pm 1,00^{\mathrm{a}}$ & $150,00 \pm 3,60^{\mathrm{b}}$ \\
Kp & $224,33 \pm 2,08^{\mathrm{a}}$ & $196,67 \pm 3,78^{\mathrm{c}}$ \\
P1 & $243,33 \pm 2,51^{\mathrm{b}}$ & $203,33 \pm 3,60^{\mathrm{d}}$ \\
P2 & $260,00 \pm 5,00^{\mathrm{c}}$ & $235,00 \pm 3,21^{\mathrm{e}}$ \\
P3 & $278,33 \pm 11,01^{\mathrm{d}}$ & \\
\hline
\end{tabular}

Total eritrosit tertinggi terdapat pada perlakuan $\mathrm{P}_{3}$, yaitu dengan pemberian pakan mengandung bakteri heterotrof isolat gabungan $B$. cereus dan $V$. fluvialis yang berjumlah $278,33 \times 10^{4} \mathrm{sel} / \mathrm{mm}^{3}$ (Gambar 4). Pemberian bakteri heterotrof mampu meningkatkan kesehatan ikan, Bacillus cereus mampu meningkatkan pencernaan ikan, meningkatkan penyerapan nutrien dan oksigen dalam darah dan mengalirkannya ke semua jaringan dan organ sehingga tingkat ketahanan tubuh terus meningkat. $V$. fluvialis bereaksi dengan antigen dalam menghasilkan antibodi. Sementara Kp tanpa pemberian bakteri heterotrof proses pencernaan lambat dan proses penyerapan nutrien pun tidak efektif sehingga memiliki sistem imun rendah dilihat dari total eritrosit paling rendah namun masih batasan normal.

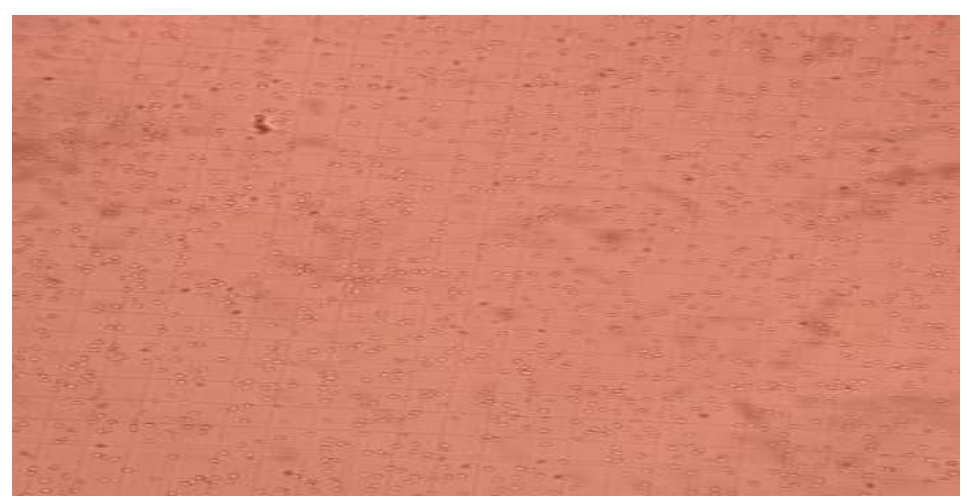

Gambar 4. Total Eritrosit Ikan Nila Salin Perlakuan P3 
Total eritrosit ikan nila salin mengalami penurunan pasca ujitantang bakteri A. hydrophila. Penurunan eritrosit mengindikasikan adanya anemia pada ikan dan senyawa haemolisin yang diproduksi oleh A. hydrophila dapat melisiskan sel eritrosit.

Menurut Collins et al., 1989 Genus bakteri Vagococcus diusulkan pada tahun 1989 untuk bakteri Gram-positif, katalasenegatif, motil, bakteri berbentuk coccus yang bereaksi dengan antigen; Antigen merupakan zat yang merangsang respons imunitas, terutama dalam menghasilkan antibodi.

Dengan demikian pemberian bakteri heterotrof isolat gabungan yang terbaik yang mampu mempertahankan jumlah eritrosit dalam darah ikan nila salin pascaujitantang bakteri patogen walaupun terjadi penurunan masih berada dalam jumlah normal.

\section{Kadar Hematokrit}

Hematokrit merupakan persentase volume eritrosit dalam darah ikan. Hasil pemeriksaan terhadap hematokrit dapat dijadikan sebagai salah satu patokan untuk menentukan keadaan kesehatan ikan, nilai hematokrit kurang dari 22\% menunjukkan terjadinya anemia (Putri et al., 2013).

Kadar hematokrit dalam darah ikan nila salin setelah pemeliharaan selama 30 hari dengan pemberian pakan mengandung bakteri heterotrof berkisar antara 30,10\% $33,33 \%$ (Tabel 3).

Tabel 3. Kadar Hematokrit pada Ikan Nila Salin (Oreochromis niloticus) dengan pemberian pakan mengandung bakteri heterotrof

\begin{tabular}{lcc}
\hline \multirow{2}{*}{ Perlakuan } & \multicolumn{2}{c}{ Kadar Hematokrit (\%) } \\
\cline { 2 - 3 } & $\begin{array}{c}\text { Hari ke-30 pemeliharaan sebelum } \\
\text { ujitantang }\end{array}$ & Hari ke 14 Pasca ujitantang \\
\hline Kn & $30,10 \pm 0,57^{\mathrm{a}}$ & $31,33 \pm 0,57^{\mathrm{c}}$ \\
Kp & $30,33 \pm 0,17^{\mathrm{a}}$ & $23,00 \pm 2,00^{\mathrm{a}}$ \\
P1 & $31,30 \pm 0,81^{\mathrm{ab}}$ & $28,00 \pm 1,00^{\mathrm{b}}$ \\
P2 & $32,00 \pm 1,00^{\mathrm{b}}$ & $29,00 \pm 1,00^{\mathrm{b}}$ \\
P3 & $33,33 \pm 0,57^{\mathrm{c}}$ & $32,00 \pm 1,00^{\mathrm{c}}$ \\
\hline
\end{tabular}

Berdasarkan hasil uji statistik (ANOVA) menunjukkan bahwa pemberian pakan mengandung bakteri heterotrof setelah 30 hari pemeliharaan memberikan pengaruh nyata terhadap kadar hematokrit ikan nila salin $(\mathrm{P}<0,05)$ Kadar hematokrit ikan nila pasca ujitantang mengalami penurunan namun dalam kisaran normal. Penurunan hematokrit dikarenakan adanya penurunan nafsu makan akibat ikan terinfeksi.

\section{Kadar Hemoglobin}

Rendahnya konsentrasi hemoglobin menunjukkan terjadinya anemia. Anemia menunjukkan kondisi dimana konsentrasi hemoglobin dalam darah rendah, yang disebabkan oleh penurunan jumlah eritrosit.

Kadar hemoglobin pada perlakuan pemberian bakteri heterotrof dapat meningkatkan pencernaan dan penyerapan nutrien dan oksigen yang kemudian di ikat hemoglobin dan dialirkan keseluruh tubuh dan dapat meningkatkan sistem. 
Tabel 4. Kadar Hemoglobin pada Ikan Nila Salin (Oreochromis niloticus) dengan Pemberian Pakan Mengandung Bakteri Heterotrof

\begin{tabular}{ccc}
\hline \multicolumn{3}{c}{ Kadar Hemoglobin $(\mathbf{g} / \mathbf{d L})$} \\
\hline Perlakuan & $\begin{array}{c}\text { Hari ke-30 pemeliharaan sebelum uji } \\
\text { tantang }\end{array}$ & $\begin{array}{c}\text { Hari ke 14 Pasca Uji } \\
\text { Tantang }\end{array}$ \\
\hline Kn & $5,33 \pm 0,57^{\mathrm{a}}$ & $5,67 \pm 0,57^{\mathrm{b}}$ \\
Kp & $5,67 \pm 0,57^{\mathrm{a}}$ & $3,83 \pm 0,28^{\mathrm{a}}$ \\
P1 & $6,33 \pm 0,57^{\mathrm{a}}$ & $4,67 \pm 0,57^{\mathrm{ab}}$ \\
P2 & $7,67 \pm 0,57^{\mathrm{b}}$ & $6,00 \pm 1,00^{\mathrm{b}}$ \\
P3 & $9,33 \pm 0,57^{\mathrm{c}}$ & $7,33 \pm 0,57^{\mathrm{c}}$ \\
\hline
\end{tabular}

Berdasarkan hasil uji statistik (ANOVA) menunjukkan kadar hemoglobin ikan nila salin yang dipelihara selama 30 hari dengan pemberian pakan mengandung bakteri heterotrof berpengaruh nyata $(\mathrm{P}<0,05)$. Hal tersebut menunjukkan bahwa pemberian pakan mengandung bakteri heterotrof mampu meningkatkan kadar hemoglobin ikan nila dengan enzim dan asam amino yang dihasilkan dapat meningkatkan kecernaan ikan sehingga meningkatkan ketahanan tubuh dan suplai oksigen yang cukup.
Banyak faktor yang mempengaruhi rendahnya kadar hemoglobin, hal ini disebabkan adanya faktor stres yang disebabkan oleh adanya infeksi bakteri patogen melisiskan darah merah sehingga menurunkan kadar oksigen.

\section{Tingkat kelulushidupan}

Rerata kelulushidupan ikan nila pemberian pakan mengandung bakteri heterotrof dapat dilihat pada Tabel 6.

Tabel 6. Kelulushidupan Ikan Nila Salin (Oreochromis niloticus) dengan Pemberian Pakan Mengandung Bakteri Heterotrof

\begin{tabular}{ccc}
\hline & \multicolumn{2}{c}{ Kelulushidupan SR(\%) } \\
\cline { 2 - 2 } Perlakuan & Hari ke-30 Pemeliharaan Pascaujitantang & Hari ke-14 Pascaujitantang \\
\cline { 2 - 3 } Kn & 86,67 & $83,33 \pm 5,77^{\mathrm{b}}$ \\
Kp & 86,67 & $43,33 \pm 5,77^{\mathrm{a}}$ \\
P1 & 83,33 & $70,00 \pm 10,00^{\mathrm{b}}$ \\
P2 & 83,33 & $73,33 \pm 5,77^{\mathrm{b}}$ \\
P3 & 86,67 & $83,33 \pm 10,00^{\mathrm{b}}$ \\
\hline
\end{tabular}

Pemberian pakan mengandung bakteri heterotrof yang dipelihara selama 30 hari memiliki kelulushidupan yang tidak jauh berbeda. Berdasarkan hasil uji statistik (ANOVA) menunjukkan kelulushidupan ikan yang dipelihara selama 30 hari dengan pemberian pakan mengandung bakteri heterotrof terlihat tidak berbeda nyata antar perlakuan $(\mathrm{P}>0,05)$

Kelangsungan hidup yang rendah pada kontrol ini terjadi karena ikan nila kontrol tanpa pemberian pakan mengandung bakteri heterotrof dan diinfeksi bakteri patogen tidak dapat melawan serangan patogen karena sistem imun yang rendah. Pada perlakuan pemberian pakan mengandung bakteri heterotrof dapat mempertahankan kelangsungan hidup dari serangan bakteri patogen dengan sistem imun yang dibentuk dari pemberian bakteri heterotrof.

\section{Kualitas Air}

Hasil pengukuran kualitas air selama penelitian meliputi oksigen terlarut (DO), 
suhu, dan $\mathrm{pH}$. Suhu air selama penelitian berkisar antara $27-28^{\circ} \mathrm{C}$. Sesuai pendapat Urbasa et al., (2015) bahwa suhu air berpengaruh terhadap pertumbuhan dan perkembangan ikan. Ikan nila dapat hidup pada suhu air berkisar antara $20-30^{\circ} \mathrm{C}$. Suhu air yang sesuai akan meningkatkan aktivitas makan ikan, sehingga menjadikan ikan nila cepat tumbuh.

Tabel 7. Kualitas Air Media Pemeliharaan Selama Penelitian

\begin{tabular}{lcccccc}
\hline \multirow{1}{*}{ Parameter } & $\mathrm{Kn}$ & $\mathrm{Kp}$ & $\mathrm{P} 1$ & $\mathrm{P} 2$ & $\mathrm{P} 3$ & SNI 7550:2009 \\
\cline { 2 - 6 } Suhu $\left({ }^{\circ} \mathrm{C}\right)$ & $27-28$ & 28 & $27-28$ & 28 & 28 & $25-32$ \\
DO $(\mathrm{mg} / \mathrm{L})$ & $3,9-5,0$ & $3,8-5,0$ & $4,0-5,0$ & $4,0-5,5$ & $4,0-5,5$ & $>3$ \\
$\mathrm{pH}$ & $7,0-8,0$ & $7,0-8,0$ & $7,0-8,0$ & $7,0-8,0$ & $7,0-8,0$ & $6,5-8.5$ \\
\hline
\end{tabular}

Kualitas perairan selama penelitian tergolong baik, bakteri heterotrof mampu mendegradasi senyawa organik dari air pemeliharaan. Parameter kualitas air yang menunjukan nilai keasaman dalam air yaitu $\mathrm{pH}$. Nilai $\mathrm{pH}$ yang diperoleh pada saat penelitian yaitu $6,7-7,1$, nilai tersebut masih tergolong baik untuk budidaya ikan nila salin. Menurut Effendi (2003), sebagian besar biota akuatik sensitif terhadap perubahan $\mathrm{pH}$ dan menyukai nilai $\mathrm{pH}$ sekitar 7-8,5. Nilai $\mathrm{pH}$ sangat mempengaruhi proses biokimiawi perairan.

\section{KESIMPULAN DAN SARAN Kesimpulan}

Bakteri heterotrof unggul yang disemprotkan pada pakan dapat meningkat- kan kesehatan ikan nila salin (O.niloticus). Hasil pemeliharaan 30 hari dan pascaujitantang menunjukkan bahwa perlakuan P3 (Isolat Gabungan) yang merupakan perlakuan terbaik dengan nilai total leukosit $89,67 \times 10^{3} \mathrm{sel} / \mathrm{mm}^{3}$, limfosit $80,33 \%$, neutrofil $10,67 \%$, monosit $9,66 \%$, total eritrosit $235,00 \times 10^{4} \mathrm{sel} / \mathrm{mm}^{3}$, hematokrit $32,00 \%$, dan hemoglobin $7,33 \mathrm{~g} / \mathrm{dL}$ serta tingkat kelulushidupan $83,33 \%$.

\section{Saran}

Selanjutnya perlu dilakukan penelitian lebih lanjut untuk melihat gambaran histopatologi ikan nila salin dengan pemberian pakan mengandung bakteri heterotrof dan pascaujitantang bakteri A. hydrophila.

\section{DAFTAR PUSTAKA}

1. Alfian, I. Lukistyowati, dan S. Henni. (2017). Pemberian Probiotik Bacillus sp Berasal dari Udang Galah (Macrobranchium rosenbergii De Man) dan Udang Windu (Penaeus monodon) Terhadap Status Kesehatan Ikan Nila (Oreochormis niloticus). Jurnal Online Mahasiswa Fakultas Perikanan dan Ilmu kelautan, Volume 4(1), Pages 1-10.

2. Aliyas, S. Ndobe., dan Y. Z. Raihani. (2016). Pertumbuhan dan Kelangsungan Hidup Ikan Nila (Oreochromis sp) yang Dipelihara Pada Media Bersalinitas. Jurnal Sains dan Teknologi Tadulako, Volume 5 (1), Pages 19-27.

3. Blaxhall, P.C, and K. W. Daisley. (1973). R Outline Haemotological Methods For Use With Fish Blood. Journal Of Fish Biology, Volume 5(6) Pages 771-781.

4. Anderson D. P., A. K Siwicki. (1993). Basic Hematology and Serology For Fish Health Programs. Aquatuc Animal Health and the Evironment, Volume 4(1) Pages 24-342.

5. Dosin, E. H. Hardi., dan Agustina. (2013). Efek Penginjeksian Produk Intraseluler (icp) dan Ekstraseluler (ecp) Bakteri Pseudomonas sp. terhadap Gambaran Darah Ikan Nila (Oreochromis niloticus). Jurnal Ilmu Perikanan Tropis. Volume 19(1) Pages 24-30. 
6. Effendie, M. I. (1979). Metode Biologi Perikanan. (p. 121). Yayasan Pustaka Nusantara: Yogyakarta

7. Feliatra, F., R. Hamdani., I. Lukistyowati., and I. Nurachmi. (2019). Sensitivity of Heterotrophic Bacteria in the Low-Salinity Water Areas and Estuary in Siak District toward Pathogenic Bacteria in Fish. International Journal of Microbiology, Volume 19(1) Pages 1-8.

8. Frandson, R.D. (1992). Anatomi dan Fisiologi Ternak. (p. 578). Edisi ke 4, Alih Bahasa oleh Sigandono, B dan Praseno, K., (Judul Asli : Anatomy and Physiology of Farm Animals). Gadjah Mada University Press. Yogyakarta.

9. Irianto, A. (2005). Patologi Ikan Teleostei. (p. 205). Gadjah Mada University Press. Yogyakarta.

10. Lukisyowati I, dan H. Syawal. (2013). Potensi Pakan yang Mengandung Sambiloto (Andrographis paniculata) dan Daun Jambu Biji (Psidium guajava) Untuk Menanggulangi Bakteri A. hydrophila Pada Ikan Baung (Mystus nemurus). Jurnal Akuakultur Rawa Indonesia, Volume 1(2) Pages 135-147.

11. Lukisyowati, I. dan Kurniasih. (2012). Kelangsungan Hidup Ikan Mas (Cyprinus carpio L) yang diberi Pakan Ekstrak Bawang Putih (Allium sativum) dan di Infeksi Aeromonas hydrophila. Jurnal Perikanan dan Kelautan, Volume 16(1) Pages 144-160

12. Nainggolan A. H., Feliatra., I. Lukistyowati. (2018). Uji Metabolit Sekunder Bakteri Heterotrofik dari Muara Sungai Siak Terhadap Bakteri Patogen. Jurnal Online Mahasiswa (JOM) Bidang Perikanan dan Ilmu Kelautan, Volume 5(2) Pages 1-13

13. Newman. S. G. (1982). Aeromonas hydrophila : A Review With Emphasis On Its Role In Fish Diseases. (pp 87-118) In: D.P. Anderson, M.Dorson and PH.Dubourget (Eds). Les Antigens des Microorganismes pathogenes des poisson. Collection Fondation Marcel Merieux.

14. Putra, A. N. (2010). Kajian Probiotik, Prebiotik dan Sinbiotik Untuk Meningkatkan Kinerja Pertumbuhan Ikan Nila (O. niloticus). Tesis. Institut Pertanian Bogor.

15. Sainah., Adelina., dan B. Heltonika. 2016. Penambahan Bakteri Probiotik (Bacillus sp) Isolasi dari Giant River Frawn (Macrobrachium rosenbergii, de man) pada Pakan Buatan untuk Meningkatkan Pertumbuhan Ikan Baung (Hemibagrus nemurus). Berkala Perikanan Terubuk, Volume 44(2) Pages 36-50

16. Setiawati, J.E., Tarsim., Adiputra., dan S. Hudaidah. (2013). Pengaruh Penambahan Probiotik Pada Pakan Dengan Dosis Berbeda Terhadap Pertumbuhan , Kelulushidupan, Efesiensi Pakan dan Retensi Protein Ikan Patin (Pangasius hypophthalmus). Jurnal Rekaya dan Tekonologi Budidaya Perairan, Volume 1(2): Pages 151-161.

17. Wedemayer GA dan WT Yasutake. 1997. Clinical Methods For The Assessment of the Effect Environment Stress on The Fish Health, Technical Papers of the US Fish and Wildlife Service. US Depart of The Interon Fish and Wildlife Service. Volume 89(1) Pages 1-17

18. Zonneveld, N. Huisman E. A. Boon, J. H. (1991). Budidaya Ikan. (p. 233). Gramedia: Jakarta. 